\title{
Genetic Variability of Tumor Necrosis Factor Receptors Type I and II in Lymphoproliferative Diseases in the Serbian Population -
}

\author{
Tatjana Jevtović-Stoimenov ${ }^{1}$, Danica Marković ${ }^{2}$, Milena Despotović1, \\ Dušica Pavlović ${ }^{1}$, Gordana Kocić1 \\ ${ }^{1}$ University of Niš, Faculty of Medicine, Institute of Biochemistry, Niš, Serbia \\ ${ }^{2}$ Center for Anesthesiology and Reanimatology, Clinical Center Niš, Niš, Serbia
}

\section{SUMMARY}

TNF-alpha and LT-alpha are involved in the pathogenesis of established lymphoproliferative diseases. Both molecules bind to TNFRI and TNFRII. TNFRI is the major mediator of the TNF pro-apoptotic and proliferative effects and TNFRII might enhance these effects. TNF receptors I and II are normally present on hematopoetic cells. TNFR II is characteristic only on immune cells, especially on peripheral leukocytes. Neoplastic $B$ cells and activated B lymphocytes have increased expression of surface TNFR I. In this study, we have analyzed polymorphisms in the TNFRI gene (TNFRI+36A/G SNP) and polymorphism in the TNFRII gene (TNFRII + 676 T/G). All these polymorphisms were studied in patients with chronic lymphocytic leukemia (CLL), patients with non-Hodkin's lymphoma (NHL) and in healthy controls. The present study was undertaken to investigate the genetic association of these polymorphisms with lymproproliferative disease development.

A total of 68 patients (49-CLL, 19-HNL) were diagnosed at the Clinic of Hematology, Clinical centre Niš, Serbia, using clinical findings and conventional morphological, cytochemical and immunological tests. Genomic DNA was isolated from isolated lymphocytes by proteinase $\mathrm{K} / \mathrm{phenol} / \mathrm{chloroform}$ method, and genotyped for TNFR I (A36G) and TNFR II (T676G) using the PCR-RFLP method.

No significant differences in allele frequencies of TNFR1 polymorphism were found between the patients with lymphoproliferative disease and healthy individuals. In a group of healthy individuals, the study has revealed for the first time significantly higher TNFRI G/G genotype compared to the patients with lymphoproliferative disease $\left(\chi^{2} 2=5.66 ; p=0.017\right)$. Also, we reported the implication of TNFRII T allele in NHL pathogenesis, respectively $\left(\chi^{2} 2=10.77 ; p=0.001\right.$; Mantel-Haenszel: $\left.\chi^{2} 2=10.64 ; p=0.0011\right)$.

Our data showed that TNFRII T676G polymorphisms have an important role in NHL pathogenesis but not in CLL patients. A/A polymorphism in TNFRI was not associated with CLL and NHL patients in the Serbian population. Investigated polymorphisms on TNFR genes in leukemic cells of CLL and NHL patients have not showed a correlation with increased proliferation of B lymphocytes and increased expression of TNF R II on B CLL lymphocytes.

Key words: TNFR, CLL, NHL, genetic polymorphism 


\section{INTRODUCTION}

Lymphoproliferative diseases represent a subgroup of immunoproliferative diseases together with hypogammaglobulinemias and paraproteinemias. This heterogeneous group of malignant neoplasms is characterized by the presence of expanding, monoclonal or oligoclonal lymph cells, which consequently leads to dysfunction of the immune system. Many types of leukemia and lymphomas are included in lymphoproliferative diseases. The risk for the onset of this kind of malignancy is certainly higher in immunocompromised people, and therefore therapy used in clinical practice should be adapted to the immune system's damage that underlies the disease $(1,2)$. Scientific progress in genetics, molecular medicine and molecular diagnostics resulted in the so-called "target therapy", aiming towards specific genetic or molecular lesions. Since therapy is very aggressive, further preclinical and clinical trials are conducted with the aim of finding new therapeutic agents with better therapeutic and lower toxic effects (3).

Chronic lymphocytic leukemia (CLL) and nonHodgkin lymphoma (NHL) represent the types of lymphoproliferative diseases and are classified as a type of mature lymphocyte neoplasm. The first discovery about genetic basis of mature lymphocyte neoplasms was that specific translocation $t(8 ; 14)(\mathrm{q} 24 ; \mathrm{q} 32)$ is responsible for the onset of these diseases. Further research was conducted with the help of new technologies used in molecular cytogenetics like FISH (fluorescent in situ hybridization) and technologies that are based on microarray-like aCGH (array comparative genomic hybridization) (4). That is how it was discovered that the most frequent chromosome aberrations underlying CLL are: trisomy of chromosome $12, \operatorname{del}(13 q), \operatorname{del}(11 q)$ and $\operatorname{del}(17 p)$. It was also found that trisomy of chromosome 12, as the most frequent mutation, is very often joined by other chromosome aberrations (5). Chromosome aberrations responsible for the onset of NHL are: $t(14 ; 18)(\mathrm{q} 32 ; \mathrm{q} 21)$ and $\mathrm{t}(3 \mathrm{q} 27)(6)$.

Numerous scientific research proved that polymorphisms of genes coding TNF- $\alpha$ and LT- $\alpha$ do have impact on the onset of lymphoproliferative diseases (7). Both cytokines function by binding to TNFRI and TNF-RII receptors, and therefore the hypothesis that says that polymorphisms of the genes that code these receptors may induct the onset and progression of these malignant diseases was set. TNF-RI is the main mediator of pro-apoptotic and proliferative effects of TNF- $\alpha$, while TNF-RII can enhance these effects. TNF-RI is expressed on a large number of tissues, while TNF-RII is expressed only on the immune cells, especially on the peripheral leukocytes. After binding to TNF-R, TNF activates one of the pathways that decide about the cells' future: NF- $k B$ (cell survival, proliferation and immune response), MAPK pathway (immune response, cell proliferation and differentiation) and death signal. Neoplastic B cells and activated B lymphocytes express TNF-RI on their surface much more than other cells. Polymorphisms of the genes that code these receptors can have impact on their function and thereby on the onset and progression of lymphoproliferative diseases $(3,8)$. In this study we have investigated the impact of the TNF-RII gene polymorphism (TNF-RI+36A/G SNP) and polymorphism of the TNF-RII gene (TNFRII+676T/G) on the onset of lymphoproliferative diseases. Both polymorphisms were investigated in the patients diagnosed with CLL and NHL and in healthy controls as well.

\section{PATIENTS AND METHODS}

Our study included 68 patients who were admitted to the Clinic for Hematology, Clinical Center Nis, Serbia. After medical examination and conventional morphological, cytochemical and immunological investigations, the patients were divided into two groups. The first group of patients was diagnosed with CLL and it included 49 patients of both sexes, mean age $66.16 \pm 11.00$ years. The second group of patients was diagnosed with NHL and it included 19 patients of both sexes, mean age $59 \pm 16.52$ years. The control group included 70 healthy participants of both sexes, with mean age $40 \pm 10$ years, who were selected randomly. All participants from the control group and patient groups came from the southeast Serbia. The study was approved by the Ethics Committee of the Faculty of Medicine Niš and fully informed written consent was obtained from each patient and control.

Lymphocytes were isolated from the whole blood mixed with EDTA, and the genomic DNA was extracted by proteinase K/phenol/chloroform method. After DNA isolation, a genotyping for TNF-RI (A36G) and TNF-RII (T676G) polymorphisms was conducted by using PCRRFLP method. PCR solution was made in the last volume of $25 \mu \mathrm{l}$, and it was made out of $20 \mathrm{ng}$ of DNA molecule, $5 \mu \mathrm{l}$ of $\mathrm{Q}$ solution, $2.5 \mu \mathrm{l}$ of 10xPCR buffer, $10 \mathrm{mM}$ of dNTP, 20 pmol of every primer (Table 1) and 0.5U of HotStarTaq DNA polymerase (Qiagen $\mathrm{GmbH}$, Hilden, Germany). Conditions for PCR were as follows: initial denaturation on $95^{\circ} \mathrm{C}$ for 15 minutes, 35 cycles of denaturation on $94^{\circ} \mathrm{C}$ for 1 minute, annealing on $50^{\circ} \mathrm{C}$ for 1 minute and extension on $72{ }^{\circ} \mathrm{C}$ for 1 minute, and then final extension on $72{ }^{\circ} \mathrm{C}$ for 10 minutes. PCR products were released on the gel electrophoresis on $2 \%$ agarose gel. The agarose gel was stained with ethidium bromide and observed under the UV light. In the case of TNR-RI, the presence of A allele on the gel was evaluated by the appearance of non-fragmented, whole length product (183bp), while the presence of $G$ allele was determined by the appearance of fragments the length of which was 108 and 75bp (Figure 1). 


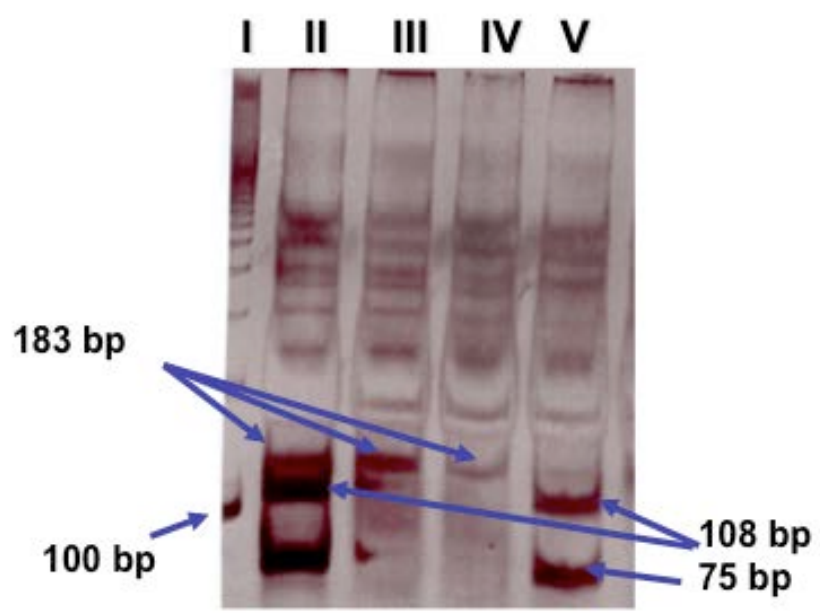

Figure 1. Digestion on 8\% AA gel. Line I 100 bp ladder; Line II, heterozigot A/G (183 bp, 108 bp i 75 bp), Line III and IV wild tip A/A (183 bp); Line V homozigot G/G (108 bp + 75 bp)

When it comes to TNF-RII, the presence of T allele on the gel was determined by the appearance of the fragments the length of which was 134 and 108bp, while the presence of $G$ allele was determined by the appearance of non-fragmented, total length product (242bp) (Figure 2).

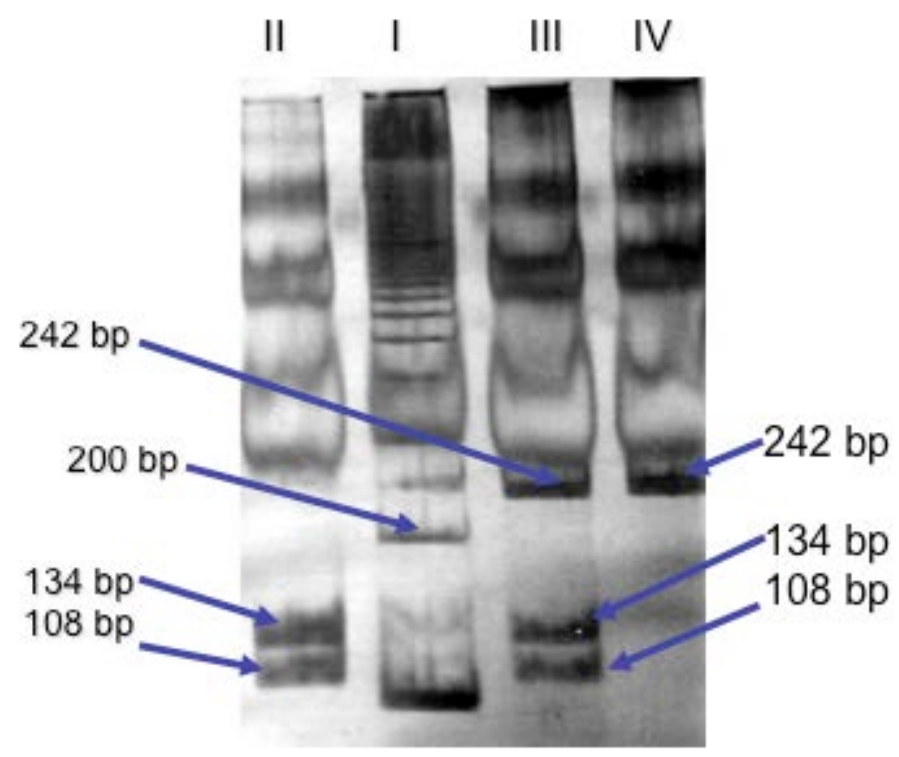

Figure 2. Digestion on $8 \%$ AA gel. Line I 100 bp ladder; Lane II wild tip T/T (134 bp + 108 bp), Line III heterozygot T/G (242 bp, 134 bp i 108 bp); Line IV homozygot G/G (242 bp)

The whole process was repeated on randomly chosen samples and after finding the positive results (especially in the case of heterozygote's). Frequencies of alleles and genotypes were determined in patients and controls using $\chi 2$ test and Mantel-Hansel test. Probability of $\mathrm{p}<0.05$ was considered statistically significant.

\section{RESULTS}

Our study on the TNF-RI gene showed statistically significant differences in the allele frequency between patients with lymphoproliferative diseases and healthy controls $\left(\chi^{2}=4.1 ; \mathrm{p}=0.043\right)$ (Table 2). Statistical processing of the genotype 
frequency data showed that the TNF-RI genotype G/G was significantly more present in the control group when compared to the patient group $\left(\chi^{2}=\right.$ 5.66; $\mathrm{p}=0.017)$. TNF-RI A/G genotype was most commonly present in the patients with NHL, while genotypes TNF-RI A/A and A/G were allied with the onset of CLL and NHL (Table 3). These results show that A36G TNF-RI gene polymorphism represents a silent mutation which is responsible for the instability of mRNA but it does not significantly influence the TNF-RI function. Also, analyses showed that A36G polymorphism is very frequently allied with T676G polymorphism on the TNF-RII gene.
When it comes to the results found after TNF-RII gene polymorphism research, we found that there exists a statistically significant difference in the frequency of $\mathrm{T}$ alleles when compared to $\mathrm{G}$ allele frequency in patients with NHL $\left(\chi^{2}=4.57 ; \mathrm{p}=\right.$ 0.032; Mantel-Haenszel: $\left.\chi^{2}=3.68 ; \mathrm{p}=0.055\right)$. More detailed view of the results is presented in Table 2. As much as $89.4 \%$ of patients with NHL had a wild type genotype $\mathrm{T} / \mathrm{T}$ (Table 3 ). The higher frequency of $\mathrm{T}$ allele in the group of patients with NHL shows that this polymorphism has an impact on the cell entrance into programmed death.

Table 1. Primers used in PCR-RFLP method for TNFRI (A36G) and TNFRII (T676G) genotyping

\begin{tabular}{|l|l|l|l|}
\hline \hline Gene & SNP & Primers & Restrictive enzymes \\
\hline $\begin{array}{l}\text { TNF- } \\
\text { RI }\end{array}$ & $\begin{array}{l}\text { A36G } \\
\text { Pro12Pro }\end{array}$ & $\begin{array}{l}\text { Forward } \\
\text { 5'-GACCCCAAATGGGGGAGTGAGAGG-3' } \\
\text { Reverse } \\
\text { 5'-ACCAGGCCCG-GGCAGGAGAG-3' }\end{array}$ & MSPA1I \\
\hline $\begin{array}{l}\text { TNF- } \\
\text { RII }\end{array}$ & $\begin{array}{l}\text { T676G } \\
\text { Met196Arg }\end{array}$ & $\begin{array}{l}\text { Forward } \\
\text { 5'-TTCTGGAGTTGGCTGCGTGT-3' } \\
\text { Reverse } \\
\text { 5'-ACTCTCCTATCCTG-CCTGCT-3' }\end{array}$ & HIN1II \\
\hline \hline
\end{tabular}

Table 2. Distribution of TNFR I and TNFR II alleles in CLL, NHL and controls

\begin{tabular}{llllll}
\hline \hline SNP & CLL & NHL & Control & & \\
Allels & $\mathbf{n}(\%)$ & $\mathbf{n}(\%)$ & $\mathbf{n}(\%)$ & $\chi^{2}$ & $p$ \\
\hline A & $110(69.62)$ & $\mathbf{2 2 ( 5 7 . 9 )}$ & $130(71.43)$ & $0.133^{\mathrm{a}}$ & $0.715^{\mathrm{a}}$ \\
$\mathbf{G}$ & $48(30.38)$ & $\mathbf{1 8 ( 4 7 . 3 6 )}$ & $52(28.57)$ & $4.1^{\mathrm{b}}$ & $0.043^{\mathrm{b}}$ \\
$\mathbf{T}$ & $69(70.4)$ & $\mathbf{3 4 ( 8 9 . 4 )}$ & $102(72.85)$ & $0.17^{\mathrm{a}}$ & $0.679^{\mathrm{a}}$ \\
$\mathbf{G}$ & $29(29.59)$ & $\mathbf{4 ( 1 0 . 5 2 )}$ & $38(27.14)$ & $4.57^{\mathrm{b}}$ & $0.032^{\mathrm{b}}$ \\
\hline \hline
\end{tabular}

n - number of subjects; CLL - chronic lymphocytic leukemia; NHL-Non-Hodgkin's lymphoma; $\chi^{2}-$ chi-squared test; $p-p$-value; ${ }^{\text {a }}$ CLL vs Control ${ }^{\mathrm{b}} \mathrm{NHL}$ vs Control 
Table 3. Distribution of TNFR I and TNFR II genotypes in investigated groups

\begin{tabular}{|c|c|c|c|c|c|c|}
\hline \multirow[b]{2}{*}{ SNP } & \multirow[b]{2}{*}{ genotype } & CLL & NHL & Control & \multirow[b]{2}{*}{$\chi^{2}$} & \multirow[b]{2}{*}{$p$} \\
\hline & & $\mathrm{n}(\%)$ & $\mathrm{n}(\%)$ & n(\%) & & \\
\hline \multirow{3}{*}{ TNFR I } & $\mathrm{AA}$ & $26(53.06)$ & $5(26.3)$ & $28(40)$ & \multirow{3}{*}{$6.9^{a}$} & \multirow{3}{*}{$0.032^{a}$} \\
\hline & & & & & & \\
\hline & AG & $23(46.04)$ & $12(63.1)$ & $24(34.3)$ & & \\
\hline \multirow[t]{2}{*}{ (A36G) } & & & & & \multirow[t]{2}{*}{$3.2^{\mathrm{b}}$} & \multirow[t]{2}{*}{$0.2^{\mathrm{b}}$} \\
\hline & GG & 0 & $2(10.5)$ & 8 (11.4) & & \\
\hline TNFR II & TT & $27(55.1)$ & 15 (78.9) & 41 (58.6) & $0.145^{\mathrm{a}}$ & $0.930^{\mathrm{a}}$ \\
\hline \multirow[t]{2}{*}{ (T676G) } & TG & 15 (30.6) & $4(21.1)$ & $20(28.6)$ & $3.7^{b}$ & $0.154^{\mathrm{b}}$ \\
\hline & GG & $7(14.3)$ & 0 & $9(12.8)$ & & \\
\hline
\end{tabular}

CLL -chronic lymphocytic leukemia; NHL-non-Hodgkin's lymphoma; $\chi 2$ - chi-squared test; ${ }^{\mathrm{a}}$ CLL vs Control ${ }^{\mathrm{b}}$ NHL vs Control $* * \mathrm{p}<0.05$

\section{DISSCUSION}

TNF receptors are called death receptors in the literature because they can activate three pathways, out of which one leads into programmed cell death, after biding of cytokines to their extracellular domain. Besides uncontrolled cell proliferation and loss of differentiation and maturation possibility, there is a third mechanism that can lead to the onset of lymphoproliferative diseases. The third mechanism represents an impairment of the cell death regulation. Each of these mechanisms is under the regulation of certain genes, and the cause of the third mechanism is considered to lie in the isolated or allied polymorphisms on some of the death receptors' genes $(9,10)$. Our research showed that the basis of lymphoproliferative diseases, especially $\mathrm{NHL}$, can lie in the cell entrance into impairment of programmed cell death regulation. Consequently, pathological accumulation of cells occurs.

More polymorphisms on the TNF-RI gene were described besides the previously mentioned chromosome aberrations that underlie lymphoproliferative diseases. TNF-RI gene is located on the chromosome 12 on the locus p13.2, and A36G polymorphism is located on the exon 1 of the TNF-RI gene. Our results showed statistically significant difference in the allele frequency in the investigated groups when compared to the control group. Therefore, we can conclude that $G$ allele has an impact on the progression of NHL. In our research, the G/G genotype showed the highest frequency in the healthy population (11.4\%), when compared to CLL (0\%) and NHL (10.5\%). Thereby, we can consider G/G genotype a characteristic of the healthy population with statistical significance. The frequency of A allele, although higher than the $G$ allele frequency in all investigated groups, cannot be considered responsible for the ethiopathogenesis of a disease because there has been no statistical significance in any case. Bartoni et al. found no statistical significance, and allele frequencies were similar to those found in our research. While our results showed A allele frequency of 0.69 and $\mathrm{G}$ allele frequency of 0.30 , Bartoni et al. found the frequency of 0.57 (A) and 0.43 (G) (11). Our investigation showed that genotype $A / G$ is more frequent in patients with NHL and is more frequently found in females (data not shown). Our results 
demonstrated that A36G polymorphism on the TNF-RI gene correlates with the onset of NHL. The available literature data prove that this polymorphism has an impact on the onset of chronic inflammatory diseases such as rheumatoid arthritis and Crohn's disease (12, 13).

Variability of the TNF-RII gene does have an impact on the receptor's structure and on the onset of a few metabolic syndromes like: hypertension, obesity, insulin resistance, and familiar hypercholesterolemia (14-16). TNF-RII gene is located on the 1p36.2 locus. It was concluded that numerous polymorphisms found on this gene can have an allied role in the pathogenesis of many diseases (17).

T676G polymorphism has an impact on the structure of this receptor in the CRD4 region, more correctly his extracellular domain, but has no impact on the TNF binding. Polymorphism is located on the exon 6 , and that part of the gene is coding a small part of transmembrane region with a proteolytic site that has function in the release of a soluble form of the receptor (18). Further research on HeLa cells showed that T676G polymorphism has a direct impact on the NF-kB activation and thereby interfere with the programmed cell death activation. That is why it is considered one of the main reasons of the HeLa cells line survival, since these cells are carriers of this specific polymorphism (19).

When it comes to the allele frequency in investigated groups, it has been proven that the frequency of $\mathrm{T}$ allele is more frequent in all investigated groups, while it has also been proven that there exists a statistically significant difference in the frequency of this allele in the group with NHL (0.89) when compared to the control group (0.27). Also, when it comes to genotypes, a higher frequency $(78.9 \%)$ of homozygote $\mathrm{T} / \mathrm{T}$ has been found in patients with NHL when compared to all other genotypes.

In the case of NHL, besides a high connection found between this disease and T676G polymorphism, we did not find literature data about this polymorphism to be considered a specific marker for the diagnosis of this disease (20-23). We only found that there exists a higher frequency of this polymorphism in chronic inflammatory diseases like familiar rheumatoid arthritis, HTLV-associated myelopathy, periodontitis, hypergonadism, etc. $(12,24,25)$.

Literature data show that a higher frequency of sTNF-RI and sTNF-RII in the plasma of patients with lymphoproliferative diseases has been found (26).
Results of Mavri et al. are in keeping with our results. Their study was conducted with the aim of showing an impact of A36G polymorphism on the level of sTNF-RI in obese women. They concluded that only $+36 \mathrm{G} / \mathrm{G}$ genotype was connected with the higher level of sTNFRI. Our results showed that A36G polymorphism on the TNF-RI gene represents a predisposition for the onset of lymphoproliferative diseases and not a cause. Also, it is not the cause of higher expression of this receptor on $\mathrm{B}$ cells and higher concentration of soluble receptors that can be found in the serum of people with CLL and NHL. Considering that $+36 \mathrm{G} / \mathrm{G}$ genotype has been found to be a characteristic of healthy people, we can confirm that this polymorphism is not responsible for the higher level of sTNF-RI in people with these diseases (27). In a study that aimed at investigating the same polymorphisms and their connection with the level of sTNF-RI and sTNF-RII in postmenopausal women, there was a conclusion that T676G polymorphism of the TNF-RII gene alone or in combination with C1690T polymorphism on the same gene is in a positive correlation with a higher level of sTNF-RII. It was also found that T676G polymorphism alone had an impact on the serum level of sTNF-RI. Our study showed a high level of connection between $+676 \mathrm{~T} / \mathrm{T}$ genotype and NHL, so we can conclude that high levels of sTNF-RI and sTNF-RII originate from T676G polymorphism (17). Another research showed the same results, i.e. there is a high level of association between these polymorphisms and the level of sTNF-RI and sTNF-RII (12).

\section{CONCLUSION}

- A36G polymorphism on TNF-RI gene represents a predisposing factor for the onset of lymphoproliferative diseases.

- T676G polymorphism on the TNF-RII gene plays an important role in the pathogenesis of NHL but not in the pathogenesis of CLL.

- Investigated polymorphisms on the genes for TNF-R in the patients with CLL and NHL did not show to have an impact on pathogenesis of lymphoproliferative diseases.

- A higher frequency of T alleles of TNFRII and G alleles of TNFR I in NHL is associated with an impairment of the entrance of cells into the programmed cell death. 


\section{References}

1. Chiorazzi N, Raj KR, Ferrarini M. Chronic lymphocytic leukemia. N Engl J Med 2005; 352(8): 804-15.

https://doi.org/10.1056/NEJMra041720

2. Goldin LR, Landgren O. Autoimmunity and Lymphomagenesis. Int J Cancer 2009; 124(7): 1497502.

https://doi.org/10.1002/ijc.24141

3. Plati J, Bucur O, Khosravi-Far R. Dysregulation of Apoptotic Signaling in Cancer: Molecular Mechanisms and Therapeutic Opportunities. J Cell biochem 2008; 104(4): 1124-49.

https://doi.org/10.1002/jcb.21707

4. Nielander I, Bug S, Richter J, et al. Combining arraybased approaches for the identification of candidate tumor suppressor loci in mature lymphoid neoplasms. AMPIS 2007; 115: 1107-34.

https://doi.org/10.1111/j.1600-

0463.2007.apm 883.xml.x

5. Stilgenbauer S, Sander S, Bullinger L, et al. Clonal evolution in chronic lymphocytic leukemia: acquisition of high-risk genomic aberrations associated with unmutated $\mathrm{VH}$, resistance to therapy, and short survival. Haematologica 2007; 92: 1242-5.

https://doi.org/10.3324/haematol.10720

6. Szymanowska N, Klapper W, Gesk S, et al. BCL2 and BCL3 are reccurent translocation partners of the IGH locus. Cancer Genet Cytogenet 2008; 186:110-4. https://doi.org/10.1016/j.cancergencyto.2008.06.00 $\underline{7}$

7. Jevtović-Stoimenov T, Kocić G, Pavlović D, et al. Polymorphisms of +250 : Possible modulation $\square-B 08$ and lymphotoxin- $\square$ tumomecrosis factor- of susceptibility to apoptosis in chronic lymphocytic leukemia and non-Hodgkin lymphoma mononuclear cells. Leukemia and Lymphoma 2008; 49(11):2163-9.

\section{https://doi.org/10.1080/10428190802381220}

8. Vistoropsky Y, Ermakov S, Reza Toliat M, et al. Genetic determinants of circulating levels of tumor necrosis factor receptor II and their association with TNF-RII gene polymorphisms. Cytokine 2010; 51(1):28-34.

https://doi.org/10.1016/j.cyto.2010.04.013

9. Watts TH. TNF/TNFR Family Members in Costimulation of $\mathrm{T}$ Cell Responses. Ann Rev Immunol 2005; 23:23-68.

https://doi.org/10.1146/annurev.immunol.23.0217 $\underline{04.115839}$

10. Plati J, Bucur O, Khosravi-Far R. Dysregulation of Apoptotic Signaling in Cancer: Molecular Mechanisms and Therapeutic Opportunities. J Cell Biochem 2008; 104(4): 1124-49.

https://doi.org/10.1002/jcb.21707

11. Barton A, John S, Ollier WER, et al. Association Between Rheumatoid Arthritis and Polymorphism of Tumor Necrosis Factor receptor II, But Not Tumor Ncerosis Factor Receptor I, in Caucasians. Arthritis Rheuma 2001; 44(1):61-5.

https://doi.org/10.1002/15290131(200101)44:1<61::AID-ANR9>3.0.CO;2-Q

12. Glossop JR, Dawes PT, Nixon NB, Mattey DL. Polymorphism in the tumour necrosis factor receptor II gene is associated with circulating levels of soluble tumour necrosis factor receptors in rheumatoid arthritis. Arthritis Res Ther 2005; 7(6): R1227-34.

https://doi.org/10.1186/ar1816

13. Waschke KA, Villani AC, Vermeire S, et al. Tumor necrosis factor receptor gene polymorphisms in Crohn's disease: association with clinical phenotypes. Am J Gastroenterol 2005;100(5):1126-33. https://doi.org/10.1111/j.1572-0241.2005.40534.x

14. Glenn CL, Wang WY, Benjafield AV, Morris BJ. Linkage and association of tumor necrosis factor receptor 2 locus with hypertension, 
hypercholesterolemia and plasma shed receptor. Hum Mol Genet 2000; 9(13): 1943-9. https://doi.org/10.1093/hmg/9.13.1943

15. Fernandez-Real JM, Vendrell J, Ricart W, et al. Polymorphism of the tumor necrosis factor-alpha receptor 2 gene is associated with obesity, leptin levels, and insulin resistance in young subjects and diet-treated type 2 diabetic patients. Diabetes Care 2000; 23(6):831-7.

https://doi.org/10.2337/diacare.23.6.831

16. Geurts JM, Janssen RG, van Greevenbroek MM, et al. Identification of TNFRSF1B as a novel modifier gene in familial combined hyperlipidemia. Hum Mol Genet 2000;9(14):2067-74.

https://doi.org/10.1093/hmg/9.14.2067

17. Kim H, Chun S, Ku SY, et al. Association between polymorphisms in tumor necrosis factor (TNF) and TNF receptor genes and circulating TNF, soluble TNF receptor levels, and bone mineral density in postmenopausal Korean women. Menopause 2009; 16(5): 1014-20.

https://doi.org/10.1097/gme.0b013e3181a039c8

18. Al-Ansari AS, Ollier WER, Villarreal J, et al. Tumor necrosis factor receptor II (TNFRII) exon 6 polymorphism in systemic lupus erythematosus. Tissue Antigens 2000; 55(1): 97-9. https://doi.org/10.1034/j.1399-0039.2000.550122.x

19. Mukhopadhyay A, Suttles J, Stout RD, Aggarwal BB. Genetic deletion of the tumor necrosis factor receptor p60 or p80 abrogates ligand-mediated activation of nuclear factor-kappa B and of mitogenactivated protein kinases in macrophages. J Biol Chem 2001;276(34):31906-12. https://doi.org/10.1074/jbc.M105252200

20. Han X, Li Y, Huang J, et al. Identification of Predictive Pathways for Non-Hodgkin Lymphoma Prognosis. Cancer Informatics 2010:9 281-92. https://doi.org/10.4137/CIN.S6315
21. Skibola CF, Bracci PM, Nieters A, et al. Tumor Necrosis Factor (TNF) and Lymphotoxin-a (LTA) Polymorphisms and Risk of Non-Hodgkin Lymphoma in the InterLymph Consortium. Am J Epidemiol 2010; 171: 267-67.

https://doi.org/10.1093/aje/kwp383

22. Cerhan JR, Novak AJ, Fredericksen ZS, et al. Risk of non-Hodgkin lymphoma in association with germline variation in complement genes. $\mathrm{Br} \mathrm{J}$ Haematol 2009; 145(5): 614-31.

https://doi.org/10.1111/j.1365-2141.2009.07675.x

23. Skibola CF, Curry JD, Nieters A. Genetic Susceptibility to Lymphoma. Haematologica. 2007; 92(7): 960-91.

https://doi.org/10.3324/haematol.11011

24. Nishimura K, Tanuma S. Presence of DNase gamma-like endonuclease in nuclei of neuronal differentiated PC12 cells. Apoptosis 1998; 3:97-103. https://doi.org/10.1023/A:1009644924530

25. Peral B, San Millan JL, Castello R, et al. Comment: the methionine 196 arginine polymorphism in exon 6 of the TNF receptor 2 gene (TNFRSF1B) is associated with the polycystic ovary syndrome and hyperandrogenism. J Clin Endocrinol Metab 2002;87(8):3977-83.

https://doi.org/10.1210/jcem.87.8.8715

26. Bojarska-Junak A, Hus I, Szczepanek EW, et al. Peripheral blood and bone marrow TNF and TNF receptors in early and advanced stages of B-CLL in correlation with ZAP-70 protein and CD38 antigen. Leukemia Res 2008; 32(2):225-33.

https://doi.org/10.1016/j.leukres.2007.06.007

27. Mavri A, Bastelica D, Poggi M, et al. Polymorphism A36G of the tumor necrosis factor receptor 1 gene is associated with PAI-1 levels in obese women. Thromb Haemost 2007; 97(1): 62-6. https://doi.org/10.1160/TH06-06-0314 


\title{
Varijacije u genima za receptore faktora nekroze tumora tip I i II kod obolelih od limfoproliferativnih bolesti u srpskoj populaciji
}

\author{
Tatjana Jevtović Stoimenovㄹ, Danica Marković², Milena Despotović1, \\ Dušica Pavlović ${ }^{1}$, Gordana Kocić ${ }^{1}$ \\ ${ }^{1}$ Univerzitet u Nišu, Medicinski fakultet, Katedra za biohemiju, Niš, Srbija \\ ${ }^{2}$ Centar za anesteziologiju i reanimatologiju, Klinički centar Niš, Niš, Srbija
}

\section{SAŽETAK}

Dosadašnja istraživanja su pokazala da TNF-alfa i LT-alfa igraju značajnu ulogu u patogenezi limfoproliferativnih bolesti. Preko TNF receptora tip I TNF alfa ostvaruje pro-apoptotične i proliferativne efekte, dok se vezivanjem za TNFR tip II ovi efekti dodatno pojačavaju. Ovi receptori su, pored normalnih hematopoetskih ćelija, prisutni i na neoplastičnim B ćelijama, dok je na aktivisanim B limfocitima dokazana povećana ekspresija TNFR I.

Cilj ove studije bio je da se analizira učestalost genotipova $i$ alela polimorfizama na genu za TNFRI (TNFRI+36A/G SNP) i genu za TNFRII (TNFRII + 676 T/G) kod bolesnika sa hroničnom limfocitnom leukemijom (HLL) i sa nehočkinskim limfomom (NHL) u odnosu na grupu zdravih ispitanika.

Ukupno je analizirano 138 ispitanika, 70 zdravih i 68 bolesnika (49-HLL, 19-HNL). Bolesnicima je potvrđena dijagnoza na Klinici za hematologiju Kliničkog centra Niš, Srbija, na osnovu kliničke slike i konvencionalnih morfoloških, citohemijskih i imunoloških testova. Genomska DNK je izolovana iz limfocita pomoću proteinaze $K$, fenol/hloroform metodom, a genotipizacija TNFR I (A36G) i TNFR II (T676G) je izvršena metodom restriktivne digestije (PCR-RFLP). Ispitivanje je odobreno od strane Etičkog komiteta Medicinskog fakulteta u Nišu.

Nije dokazana statistički značajna razlika u frekvenci G i A alela na genu za TNFRI kod bolesnika sa HLL i NHL u odnosu na grupu zdravih ispitanika. Istraživanja su pokazala značajno veću učestalost TNFRI G/G genotipa u poređenju sa bolesnicima sa HLL i NHL $\left(\left(\chi^{2} 2=5,66 ; p=0,017\right)\right.$. Takođe je dokazana veća učestalost TNFRII T alela kod bolesnika sa NHL $\left(\left(\chi^{2} 2=10,77 ; p=0,001\right.\right.$; Mantel-Haenszel: $\left(\chi^{2} 2=10,64 ; p=0,0011\right)$.

Ispitivanja su pokazala da TNFRII T676G polimorfizam ima značajnu ulogu u patogenezi NHL, ali ne i u patogenezi HLL. A/A genotip TNFRI polimorfizma nije udružen ni sa HLL ni sa NHL kod bolesnika u srpskoj populaciji.

Ključnereči: faktor nekroze tumora, receptori, hronična limfocitna leukemija, nehočkinski limfom, genetički polimorfizam 